\title{
Molecular underpinnings of Fe(III) oxide reduction by Shewanella oneidensis MR-1
}

\author{
Liang Shi ${ }^{1}{ }^{*}$, Kevin M. Rosso ${ }^{1}$, Tomas A. Clarke ${ }^{2}$, David J. Richardson ${ }^{2}$, John M. Zachara ${ }^{1}$ and \\ James K. Fredrickson ${ }^{1}$
}

1 Pacific Northwest National Laboratory, Richland, WA, USA

2 University of East Anglia, Norwich, UK

\section{Edited by:}

David Emerson, Bigelow Laboratory

for Ocean Sciences, USA

Reviewed by:

Jeffrey A. Gralnick, University of

Minnesota, USA

Joel Weiner, University of Alberta,

Canada

*Correspondence:

Liang Shi, Microbiology Group, Pacific Northwest National Laboratory, 902

Battelle Blvd., P.O. Box 999, Richland, WA, USA.

e-mail: liang.shi@pnnl.gov
In the absence of $\mathrm{O}_{2}$ and other electron acceptors, the Gram-negative bacterium Shewanella oneidensis MR-1 can use ferric [Fe(III)] (oxy)(hydr)oxide minerals as the terminal electron acceptors for anaerobic respiration. At circumneutral $\mathrm{pH}$ and in the absence of strong complexing ligands, Fe(III) oxides are relatively insoluble and thus are external to the bacterial cells. S. oneidensis MR-1 and related strains of metal-reducing Shewanella have evolved machinery (i.e., metal-reducing or Mtr pathway) for transferring electrons from the inner-membrane, through the periplasm and across the outer-membrane to the surface of extracellular Fe(III) oxides. The protein components identified to date for the Mtr pathway include CymA, MtrA, MtrB, MtrC, and OmcA. CymA is an inner-membrane tetraheme $c$-type cytochrome (c-Cyt) that belongs to the $\mathrm{NapC} / \mathrm{NrfH}$ family of quinol dehydrogenases. It is proposed that CymA oxidizes the quinol in the inner-membrane and transfers the released electrons to MtrA either directly or indirectly through other periplasmic proteins. A decaheme $c$-Cyt, MtrA is thought to be embedded in the trans outer-membrane and porinlike protein MtrB. Together, MtrAB deliver the electrons through the outer-membrane to the $\mathrm{MtrC}$ and OmcA on the outmost bacterial surface. MtrC and OmcA are the outer-membrane decaheme $c$-Cyts that are translocated across the outer-membrane by the bacterial type II secretion system. Functioning as terminal reductases, $\mathrm{MtrC}$ and $\mathrm{OmcA}$ can bind the surface of Fe(III) oxides and transfer electrons directly to these minerals via their solvent-exposed hemes. To increase their reaction rates, MtrC and OmcA can use the flavins secreted by S. oneidensis MR-1 cells as diffusible co-factors for reduction of Fe(III) oxides. Because of their extracellular location and broad redox potentials, MtrC and OmcA can also serve as the terminal reductases for soluble forms of Fe(III). In addition to Fe(III) oxides, Mtr pathway is also involved in reduction of manganese oxides and other metals. Although our understanding of the Mtr pathway is still far from complete, it is the best characterized microbial pathway used for extracellular electron exchange. Characterizations of the Mtr pathway have made significant contributions to the molecular understanding of microbial reduction of $\mathrm{Fe}(\mathrm{III})$ oxides.

Keywords: dissimilatory $\mathrm{Fe}(\mathrm{III})$ oxide reduction, Shewanella oneidensis MR-1, extracellular electron transfer pathway, $c$-type cytochromes with multiple hemes, molecular biology

\section{INTRODUCTION}

The Gram-negative bacterium Shewanella oneidensis MR-1 can use ferric [Fe(III)] (oxy)(hydr)oxide minerals as the terminal electron acceptors for anaerobic respiration [i.e., dissimilatory Fe(III) reduction] (Myers and Nealson, 1990). Dissimilatory reduction of $\mathrm{Fe}(\mathrm{III})$ oxides by microorganisms plays a critical role in the biogeochemical cycle of Fe (Weber et al., 2006). At circumneutral $\mathrm{pH}$ and in the absence of strong complexing ligands, $\mathrm{Fe}$ (III) oxides are usually sparingly soluble in water and their redox potentials vary, which depend on their phases and range from -300 to $0 \mathrm{mV}$ (Thamdrup, 2000). Because of their insolubility in water, $\mathrm{Fe}$ (III) oxides are unable to cross the bacterial outer-membrane to the periplasm and the cytoplasmic or inner-membrane where the bacterial terminal reductases are usually located. To overcome this physical barrier, S. oneidensis MR-1 and other metal-reducing Shewanella have developed the ability to transfer electrons from the inner-membrane where electrons are accumulated from bacterial metabolic activity to the bacterial cell surface where reduction of Fe(III) oxides occurs. Gene inactivation and subsequent phenotypic analyses of $S$. oneidensis MR-1 mutants have identified several proteins directly involved in this electron transfer system. These include four $c$-type cytochromes (c-Cyts) CymA, MtrA, $\mathrm{MtrC}$, and OmcA and a trans outer-membrane and porin-like protein MtrB (Table 1; Myers and Myers, 1997a,b, 2002; Beliaev and Saffarini, 1998; Beliaev et al., 2001; Lies et al., 2005; Gorby et al., 2006; Bretschger et al., 2007; Coursolle and Gralnick, 2010; Reardon et al., 2010). Together, they form a pathway (i.e., Mtr pathway) through which electrons move from the quinone/quinol 
Table 1 | Identified protein components of Mtr pathway.

\begin{tabular}{llcl}
\hline Name & Locus tag & Number of heme & Location \\
\hline CymA & SO_4591 & 4 & Inner-membrane \\
MtrA & SO_1777 & 10 & Outer-membrane \\
MtrB & SO_1776 & 0 & Outer-membrane \\
MtrC & SO_1778 & 10 & Outer-membrane \\
OmcA & SO_1779 & 10 & Outer-membrane
\end{tabular}

pool in the inner-membrane, through the periplasm and across the outer-membrane to the surface of $\mathrm{Fe}$ (III) oxides (for recent reviews, see Richardson, 2000; Shi et al., 2007, 2009; Fredrickson and Zachara, 2008; Fredrickson et al., 2008). Investigation of the Mtr pathway not only has advanced our understanding of molecular mechanisms by which microbial cells transfer electrons to the external environment, such as for the reduction of $\mathrm{Fe}(\mathrm{III}) \mathrm{min}$ erals, but also will enable improved applications of S. oneidensis MR-1 and other metal-reducing Shewanella in microbial fuel cells and for electrobiosynthesis of valuable bio-materials (Hau and Gralnick, 2007; Fredrickson et al., 2008; Ross et al., 2011).

In S. oneidensis MR-1, the genes encoding MtrABC and OmcA are clustered in a sequential order of $o m c A-m t r C-m t r A-m t r B$. Comparative analysis of the genomes of 19 metal-reducing Shewanella strains reveals that $m t r C-m t r A-m t r B$ genes are well conserved, while $o m c A$ is sometimes replaced by undA or undA1, the genes predicted to encode 11-heme $c$-Cyts (Fredrickson et al., 2008; Shi et al., 2011). PCR analysis of seven metal-reducing Shewanella strains isolated from the Hanford Reach of the Columbia River also indicates that all tested strains possess an $m t r C$ homolog, while three strains have an $o m c A$ homolog, and the remaining four strains contain an undA1 homolog. Thus, essentially all characterized metal-reducing Shewanella strains contain $\mathrm{mtr}$ and related genes that are originally identified from $S$. oneidensis MR-1 (Shi et al., 2011). S. oneidensis MR-1 and other metalreducing Shewanella are key contributors to metal redox cycling in energy-rich gradient environments where electron acceptor type and availability, including $\mathrm{Fe}(\mathrm{III})$ and $\mathrm{Mn}$ oxides, vary spatially and temporally (Nealson and Scott, 2003). The respiratory versatility enabled by the Mtr pathway allows Shewanella to effectively compete with other microorganisms in environments where such solid-phase electron acceptors are common. In addition to $\mathrm{Fe}(\mathrm{III})$ oxide reduction, MtrAB homologs are also involved in the electron transfer reactions for extracellular reduction of dimethylsulfoxide (DMSO) by S. oneidensis MR-1 and extracellular Fe(II) oxidation by Rhodopseudomonas palustris TIE-1 (Gralnick et al., 2006; Jiao and Newman, 2007). A survey of recently finished genomes of the $\mathrm{Fe}(\mathrm{II})$-oxidizing bacteria Gallionella ferruginea ES-2 and Sideroxydans lithotrophicus ES-1 reveals that each genome has a pair of $m t r A B$ homologs that are clustered together, indicating that MtrAB homologs may also be widely employed by the Gramnegative bacteria for extracellular Fe(II) oxidation (L. Shi, personal observation).

Shewanella oneidensis MR-1 secretes water-soluble molecules that function either as electron shuttles or $\mathrm{Fe}(\mathrm{III})$ complexing ligands to enhance $\mathrm{Fe}(\mathrm{III})$ oxide reduction (Marsili et al., 2008; von Canstein et al., 2008; Jones et al., 2010). Non-biogenic organic shuttle molecules, such as anthraquinone disulfonate, are also well known to accelerate $\mathrm{Fe}(\mathrm{III})$ oxide reduction rates (Zachara et al., 1998), in part because of thermodynamically accessible redox potentials, and in part because of intrinsically fast electron transfer kinetics (Rosso et al., 2004). Quinones and molecules bearing quinone moieties have been shown to be particularly efficient electron transfer mediators to Fe(III) oxides (Stack et al., 2004). These molecules exert or are thought to exert their roles in $\mathrm{Fe}(\mathrm{III})$ oxide reduction by working in concert with the Mtr pathway (Ross et al., 2009; Shi et al., 2009; Coursolle and Gralnick, 2010; Jones et al., 2010). Extracellular appendages or nanowires are also observed to be associated with S. oneidensis MR-1 cells where they are believed to be involved in $\mathrm{Fe}(\mathrm{III})$ oxide reduction. Key components of the Mtr pathway, such as MtrC and OmcA, have been implicated as important electron transfer proteins in the Shewanella nanowires (Gorby et al., 2006; El-Naggar et al., 2008, 2010). This review focuses on our current understandings of functional roles of the identified protein components of the Mtr pathway in the electron transfer reactions during extracellular $\mathrm{Fe}$ (III) oxide reduction by S. oneidensis MR-1.

\section{CymA IS THE ENTRY POINT OF THE Mtr PATHWAY}

Tetraheme $c$-Cyt CymA is a member of the NapC/NrfH family of quinol dehydrogenases that are critical for quinol oxidation during bacterial anaerobic respiration (Simon and Kern, 2008). In addition to $\mathrm{Fe}(\mathrm{III})$ oxide reduction, CymA is also required for reducing DMSO, fumarate, nitrate, and nitrite by S. oneidensis MR-1 and for reducing arsenate by Shewanella sp. strain ANA3 and S. putrefaciens CN-32 (Myers and Myers, 1997a; Schwalb et al., 2003; Murphy and Saltikov, 2007). The N-terminal region of CymA polypeptide contains a single trans-membrane domain that anchors CymA to the inner-membrane, and the rest of the CymA polypeptide covalently binds four heme groups and protrudes into the periplasm. The periplasmic portion of $\mathrm{CymA}\left(\mathrm{CymA}_{\mathrm{sol}}\right)$ can reduce DMSO, fumarate, and nitrite in vivo (Schwalb et al., 2003). Likewise, purified $\mathrm{Cym}_{\text {sol }}$ transfers electrons directly to the fumarate reductase FccA of S. oneidensis MR-1 with an apparent second-order rate constant of $19 \mu \mathrm{M}^{-1} \mathrm{~s}^{-1}$ (Schwalb et al., 2003). Cym $A_{\text {sol }}$ has a broad redox potential ranging from $\sim-350$ to $\sim 0 \mathrm{mV}$ vs. the standard hydrogen electrode (SHE), which is similar to the redox potential measured for the membrane-bound CymA of S. frigidimarina NCIMB400 (Field et al., 2000; FirerSherwood et al., 2008). Like other members of the NapC/NrfH family of quinol dehydrogenases, CymA is believed to oxidize quinol in the inner-membrane and transfer the released electrons to redox proteins located in the periplasm. Purified CymA of $S$. frigidimarina NCIMB400 indeed can be reduced by duroquinol and menaquinol in vitro (Field et al., 2000). Structural determination of $\mathrm{NrfH}$ of Desulfovibrio vulgaris, which is the only available molecular structure for the $\mathrm{NapC} / \mathrm{NrfH}$ family of quinol dehydrogenases, reveals that quinol binds in a pocket adjacent to the heme 1 of $\mathrm{NrfH}$ of $D$. vulgaris, where quinol oxidation occurs (Rodrigues et al., 2006, 2008). Heme 1 of $\mathrm{NrfH}$ of D. vulgaris is unique in terms of its coordination. Its proximal axial ligand is a methionine residue (Met49) that is two residues downstream from the histidine residue of the $\mathrm{CX}_{2} \mathrm{CH}$ motif for binding of heme 1 , and an aspartate residue (Asp89) is at the position usually 
occupied by the distal axial ligand. However, Asp89 is not used for heme coordination; rather, it binds quinol (Rodrigues et al., 2006, 2008). Consequently, heme 1 of $\mathrm{NrfH}$ of $D$. vulgaris is a single methionine-coordinated, high-spin heme (Rodrigues et al., 2006). In contrast to $\mathrm{NrfH}$ of D. vulgaris, neither Met49 nor Asp89 is conserved in the CymA of S. oneidensis MR-1. In fact, purified CymA of $S$. frigidimarina NCIMB400 contains four low-spin hemes each of which is most likely coordinated in the axial positions by two histidine residues (Field et al., 2000). Thus, it is still unclear how CymA binds and oxidizes quinol at the molecular-level.

Unlike $\mathrm{NrfH}$ of $D$. vulgaris that forms a stable complex with NrfA, the interactions between CymA and its redox partners in the periplasm appear weak because CymA can be easily purified to homogeneity from $S$. frigidimarina NCIMB400 (Field et al., 2000; Rodrigues et al., 2006, 2008). The apparent transient nature of the protein-protein interactions between CymA and its redox partners in the periplasm may be attributed to the fact that CymA interacts with different periplasmic proteins, such as NrfA and FccA, depending on the nature of the terminal electron acceptors. Weak interactions would permit CymA considerable flexibility with regards to its binding partners in response to electron acceptors. Periplasmic proteins small tetraheme cytochrome (STC, also known as CctA), MtrA, and FccA are all proposed to receive electrons from CymA during Fe(III) oxide reduction (Ross et al., 2007; Shi et al., 2007; Schuetz et al., 2009). In vivo chemical cross-linking, however, fails to detect any physical interaction between CymA and STC or MtrA (Ross et al., 2007). In vitro, direct electron transfer has been demonstrated between CymA and MtrA, FccA, or STC and between MtrA and FccA, but not between STC and MtrA (Schwalb et al., 2003; Schuetz et al., 2009; Firer-Sherwood et al., 2011b). Investigation of reverse electron transfer reactions from electrode surfaces through the Mtr pathway to the periplasmic FccA suggests that electron transfer between MtrA and FccA is facilitated by CymA, while direct electron transfer from MtrA to FccA is minimal (Ross et al., 2011). Furthermore, deletion of cctA or $f c c A$ has little impact on $\mathrm{Fe}(\mathrm{III})$ oxide reduction by $S$. oneidensis MR-1 (Schuetz et al., 2009; Coursolle and Gralnick, 2010). Collectively, all these results suggest that neither STC nor FccA play a major role in mediating electron transfer between CymA and MtrA during extracellular reduction of $\mathrm{Fe}(\mathrm{III})$ oxides.

Survey of the genome of the neutrophilic Fe(II)-oxidizing bacterium S. lithotrophicus ES-1 identifies a cymA homolog located next to a pair of $m \operatorname{tr} A B$ homologs, $m t o A B$, in a sequential order of $m$ to $A-m t o B-c y m A$. This finding raises a possibility that CymA homolog may also be involved in $\mathrm{Fe}$ (II) oxidation, in which it may serve as a quinone reductase.

\section{MtrA AND MtrB TRANSLOCATE THE ELECTRONS ACROSS THE OUTER-MEMBRANE TO THE MtrC AND OmcA LOCATED OUTSIDE OF BACTERIAL CELLS}

MtrA can be purified, following overexpression, from either $S$. oneidensis MR-1 or Escherichia coli. Purified MtrA contains 10 lowspin hemes with a redox potential ranging from -400 to $-100 \mathrm{mV}$ vs. SHE (Pitts et al., 2003; Shi et al., 2005; Firer-Sherwood et al., 2008, 2011b). In vivo cross-linking with formaldehyde indicates a physical interaction between MtrA and MtrB (Ross et al., 2007). When Triton X-100 is used as a solubilizing reagent, MtrABC can be isolated as a protein complex with a stoichiometry of 1:1:1 (Ross et al., 2007; Hartshorne et al., 2009). The purified MtrABC complex can transfer electrons across a lipid bilayer following incorporation into proteoliposomes, providing direct evidence that together, MtrABC serve as an electron conduit between the periplasm of S. oneidensis MR-1 cells and its extracellular environments (Hartshorne et al., 2009). Consistent with these results, heterologous co-expression of MtrABC enables E. coli to reduce solid-phase Fe(III) oxides (Jensen et al., 2010). Furthermore, while MtrAB can form a stable complex in the absence of MtrC, an MtrBC complex cannot be isolated in the absence of MtrA. When MtrB is present, MtrA only associates with the bacterial membrane, presumably with MtrB that spans the outer-membrane. Measurement by sedimentation equilibrium indicates a high binding affinity $\left(K_{\mathrm{d}}<0.1 \mu \mathrm{M}\right)$ between MtrAB and MtrC. Based on these findings, it is proposed that MtrB is a trans outer-membrane spanning $\beta$-barrel protein that serves as a sheath to embed MtrA in the membrane where MtrAB form a trans outer-membrane delivery module for transferring electrons to MtrC, which functions as an extracellular reductase (Hartshorne et al., 2009). This is the first molecular model of electron transfer across the bacterial outer-membrane, which we hypothesize will apply more broadly to a number of bacterial genera that either gain energy by oxidizing extracellular substrates, such as $\mathrm{Fe}$ (II), or reducing compounds such as DMSO as part of anaerobic respiration (Hartshorne et al., 2009).

MtrA contains a signal peptide that targets the synthesized polypeptide to the periplasm via the bacterial Sec system. The MtrA polypeptides can be divided into two pentaheme domains, each of which shares sequence similarity with $\mathrm{NrfB}$ of $E$. coli (Beliaev and Saffarini, 1998; Clarke et al., 2007, 2008). When it is expressed in E. coli, the truncated MtrA with only one of its pentaheme domains is folded properly and possesses five hemes, providing experimental evidence that MtrA contains two repetitive functional domains (Clarke et al., 2008). The molecular structure of $\mathrm{NrfB}$ of $E$. coli has been determined and contains five closely packed hemes ( $<6 \AA$ between neighboring hemes) with a maximal edge to edge distance of $40 \AA$. This type of heme arrangement permits rapid electron transfer among the heme groups of $\mathrm{NrfB}$ that form a molecular wire (Figure 1; Clarke et al., 2007, 2008). The heme groups $\mathrm{NrfH}$ of $D$. vulgaris are also closely packed in a nearly linear array with a maximal edge to edge distance of $13 \AA$ (Rodrigues et al., 2006). Based on the structures of NrfB of E. coli and $\mathrm{NrfH}$ of $D$. vulgaris, one could speculate that the heme groups of MtrA may also form a molecular wire that could be $80 \AA$ long, while those in CymA may form a 13 - $\AA$-long molecular wire. Consistent with this idea, measurements with small angle X-ray scattering show that MtrA adapts to a flat elongated shape with overall dimensions of $104 \AA \times 20 \AA \times 50 \AA$ (Firer-Sherwood et al., 2011a). Because MtrB is thought to be a porin-like protein with an estimated pore size that is $>30 \AA \times 40 \AA$, MtrA can, in principle, be embedded at least partially in MtrB (Firer-Sherwood et al., 2011a).

Given that the thickness of the Gram-negative bacterial outermembrane is $\sim 70 \AA$ (or $7 \mathrm{~nm}$; Matias et al., 2003), the estimated length of MtrA is sufficient for transferring electrons heme-toheme across the entire outer-membrane. However, the periplasmic width of S. oneidensis MR-1 is $235 \pm 37 \AA$ (Dohnalkova et al., 

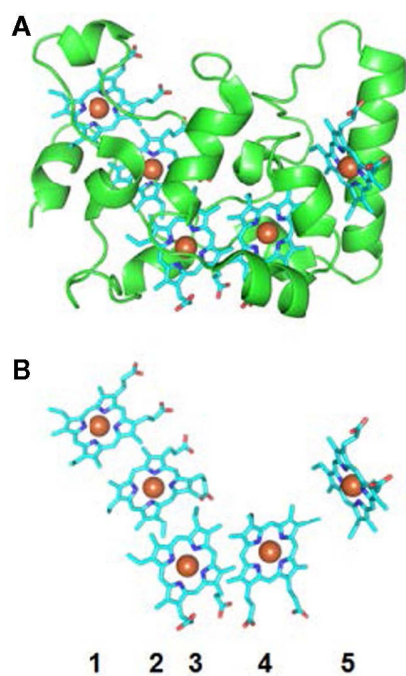

FIGURE 1 | Molecular structure of NrfB of E. coli. (A) Crystal structure of NrfB (PDB-ID: 2OZY) showing the peptide chain (green) and hemes (Blue). (B) Arrangement of NrfB hemes shown in the same orientation as panel (A). The hemes are numbered according to the position of their corresponding $\mathrm{CXXCH}$ binding motif in the NrfB amino acid sequence.

2011), too great a distance for a pair of MtrA and CymA to bridge. Additional periplasmic redox proteins thus appear to be necessary for conducting electrons between CymA in the inner-membrane and MtrA in the outer-membrane. The periplasmic redox protein involved in this aspect of electron transfer chain, however, has not been identified. As discussed in the previous section, STC and FccA, two of the most abundant redox proteins in the periplasm of $S$. oneidensis MR-1, do not appear to mediate electron transfer between CymA and MtrA. Given that $\mathrm{NrfH}$ of D. vulgaris (i.e., a CymA homolog) and NrfB of E. coli (i.e., an MtrA homolog) all physically interact with NrfA, and that heterologously expressed MtrA of S. oneidensis MR-1 exchanges electrons with the NrfA in E. coli (Pitts et al., 2003), it seems possible that NrfA may conduct the electrons between CymA and MtrA during Fe(III) oxide reduction (Shi et al., 2007). Alternatively, CymA may be localized in the periplasmic regions that are sufficiently close enough for direct electron transfer between CymA and MtrA as demonstrated in vitro (Matias et al., 2003; Schuetz et al., 2009; Firer-Sherwood et al., 2011b).

\section{MtrC AND OmcA ARE THE TERMINAL REDUCTASES OF Fe(III) OXIDES}

MtrC and OmcA are two outer-membrane $c$-Cyts located on the bacterial surface where they are translocated across the outermembrane by the bacterial type II secretion system (DiChristina et al., 2002; Myers and Myers, 2003; Donald et al., 2008; Shi et al., 2008; Lower et al., 2009; Reardon et al., 2010). Following expression in S. oneidensis MR-1, OmcA is co-isolated with MtrC when they are solubilized with $n$-octyl- $\beta$-D-glucopyranoside. In vitro characterization shows that purified MtrC and OmcA form a stable complex $\left(K_{\mathrm{d}}<500 \mathrm{nM}\right)$ with a stoichiometry of 1:2 (Shi et al., 2006). Subsequent in vivo cross-linking with different chemical reagents consistently demonstrates that MtrC and OmcA physically interact with each other on the bacterial cells (Ross et al., 2007; Tang et al., 2007; Zhang et al., 2008, 2009). The physical interaction between MtrC and OmcA synergistically enhances the metal reductase activity of MtrC and OmcA (Shi et al., 2006).

Purified MtrC and OmcA, each of which contains 10 hemes, show broad redox potentials ranging from -400 to $100 \mathrm{mV}$ vs. SHE and -320 to $-20 \mathrm{mV}$ vs. SHE, respectively (Shi et al., 2006; Hartshorne et al., 2007; Firer-Sherwood et al., 2008). Both UVvisible spectropotentiometric titrations and electron paramagnetic resonance (EPR) analyses show that MtrC has only low-spin hemes (Hartshorne et al., 2007), while EPR measurement reveals at least one high-spin heme in OmcA, although UV-visible spectropotentiometric titrations fail to detect it (Bodemer et al., 2010). Scanning tunneling microscopy and tunneling spectroscopy show that $\mathrm{MtrC}$ and OmcA immobilized on gold surfaces have distinct current-voltage $(I-V)$ tunneling spectra at the single-molecule level (Wigginton et al., 2007a,b). Theoretical interpretation of their $I-V$ spectra suggest that MtrC and OmcA possess different electron transfer properties, related to apparent participation of MtrC hemes with redox potentials between -81 and $-365 \mathrm{mV}$ vs. SHE, whereas for OmcA no heme participation is detectable by single-molecule tunneling spectroscopy. It is proposed that in this measurement, conductance is through the peptide backbone of OmcA (Wigginton et al., 2007a). However, in other measurements, the heme groups of OmcA are involved in electron transfer to metal ions (Shi et al., 2006; Xiong et al., 2006; Borloo et al., 2007; Marshall et al., 2008; Wang et al., 2008; Ross et al., 2009; Reardon et al., 2010). These different results can probably be attributed to the different methods used for the measurements. Nevertheless, all these measurements consistently show that MtrC and OmcA possess different electron transfer properties (Marshall et al., 2006, 2008; Shi et al., 2006; Borloo et al., 2007; Wigginton et al., 2007b; Wang et al., 2008; Reardon et al., 2010; Belchik et al., 2011). The distinct electron transfer properties observed for MtrC and OmcA suggest different physiological roles for these $c$-Cyts during metal reduction (Shi et al., 2006; Wigginton et al., 2007b).

Interactions between purified $\mathrm{MtrC}$ or OmcA and $\mathrm{Fe}$ (III) oxides have been extensively investigated using a variety of methods. Analyses with co-sedimentation and fluorescence correlation spectroscopy show that OmcA binds hematite $\left(\alpha-\mathrm{Fe}_{2} \mathrm{O}_{3}\right)$ directly with a partition coefficient of $\sim 2 \times 10^{5}\left(\Delta G^{0^{\prime}}=-28 \mathrm{~kJ} / \mathrm{mol}\right)$, which corresponds to $10^{14} \mathrm{OmcA}$ molecules per $\mathrm{cm}^{2}$ of hematite (Xiong et al., 2006). Similar binding affinity to hematite is also observed for OmcA using neutron reflectometry (Johs et al., 2010). Atomic force microscopy measurements reveal that MtrC and OmcA bind hematite with distinct force characteristics. The binding strength of OmcA to hematite is approximately twice that for $\mathrm{MtrC}$, while the binding frequency of MtrC to hematite is twice that for OmcA (Lower et al., 2007). Measured force signatures with purified MtrC and OmcA also correlate well with those measured with intact cells (Lower et al., 2001), a finding that supports the direct electron transfer to $\mathrm{Fe}$ (III) oxide by MtrC and OmcA (Lower et al., 2007). Screening with phage-display technology identifies a polypeptide with a conserved hematite-binding motif of Ser/Thrhydrophobic/aromatic-Ser/Thr-Pro-Ser/Thr. Molecular dynamics simulation with Ser-Pro-Ser polypeptide and hematite suggests 
that Ser-Pro-Ser peptide binds hematite via the hydrogen bonds formed between the two serine residues and hydroxylated hematite surface, while the proline residue helps stabilize the binding by limiting the peptide flexibility. The putative hematite-binding motif of Thr-Pro-Ser/Thr is found close to heme 10 of both MtrC and OmcA polypeptides (Lower et al., 2008).

Measurements with spectroscopy and protein film voltammetry consistently show that purified MtrC and OmcA transfer electrons directly to hematite with the rate constants ranging from 0.025 to $63.5 \mathrm{~s}^{-1}$ (Xiong et al., 2006; Eggleston et al., 2008; Meitl et al., 2009). Most important, the voltammograms of purified MtrC and OmcA on hematite electrodes are very similar to those of the S. oneidensis MR-1 cells expressing only the corresponding outer-membrane $c$-Cyt, suggesting that MtrC and OmcA on the bacterial surface exchange electrons directly with hematite (Meitl et al., 2009). Furthermore, MtrC and OmcA are co-localized with hematite and secondary mineral phases after ferrihydrite reduction by $S$. oneidensis MR-1 and E. coli cells with heterologously expressed MtrABC reduce solid-phase Fe(III) oxide in the absence of any mediators such as flavins (Lower et al., 2009; Jensen et al., 2010; Reardon et al., 2010). Taken together, these results demonstrate that MtrC and OmcA are the terminal reductases that bind and reduce $\mathrm{Fe}$ (III) oxides directly.

Compared to measurements with intact cells and the total membrane fraction, purified $\mathrm{MtrC}$ and OmcA reduce goethite $[\alpha-\mathrm{FeO}(\mathrm{OH})]$ at much slower rates. Addition of flavin, however, increases the rates comparable to those measured with intact cells and the total membrane fraction. Further investigations show that OmcA reduces flavins much faster than flavins reduce goethite, suggesting an electron shuttle role for flavins during MtrC- and OmcA-mediated reduction of Fe(III) oxides (Ross et al., 2009). Consistent with this suggestion, the Mtr pathway is required for in vivo reduction of flavins by $S$. oneidensis MR-1 cells (Coursolle et al., 2010).

Recent determination of the molecular structure of MtrF, an MtrC homolog, at a resolution of $3.2 \AA$ has provided the unprecedented molecular structural evidence supporting the terminal reductase role for the outer-membrane $c$-Cyts of S. oneidensis MR1 in Fe(III) oxide reduction (Clarke et al., 2011). Results show that MtrF is folded into four distinct domains: domains I (aa 49-186) and III (aa 319-473) each contains seven anti-parallel $\beta$-strands folded together to form a split- $\beta$ barrel structure, while domains II (aa 187-318) and IV (aa 474-641) each bind five tightly packed hemes (Figure 2A). The four domains fold together so that the pentaheme domains II and IV are packed to form a central core with the two split- $\beta$ barrel domains I and III flanking either side. This organizes 10 hemes of MtrF into a unique "wire cross," in which a staggered $65-\AA$ octaheme chain (hemes $10,9,8,6,1,3$, $4,5)$ transects the length of the protein through domains IV and II and is crossed at the middle by a $45-\AA$ tetraheme chain (hemes $2,1,6,7)$ that connects the two split $\beta$-barrel domains I and III. This "wire cross" is made up of a lower order organization of two triads of parallel hemes (hemes 3, 4, 5 and hemes 8, 9, 10) that lie perpendicular to a quartet of parallel hemes. Each heme is within $7 \AA$ of its nearest neighbor(s), permitting rapid electron transfer among the hemes (Figure 2B). It is proposed that domain II interacts with solid-phase Fe(III) oxides by transferring electrons

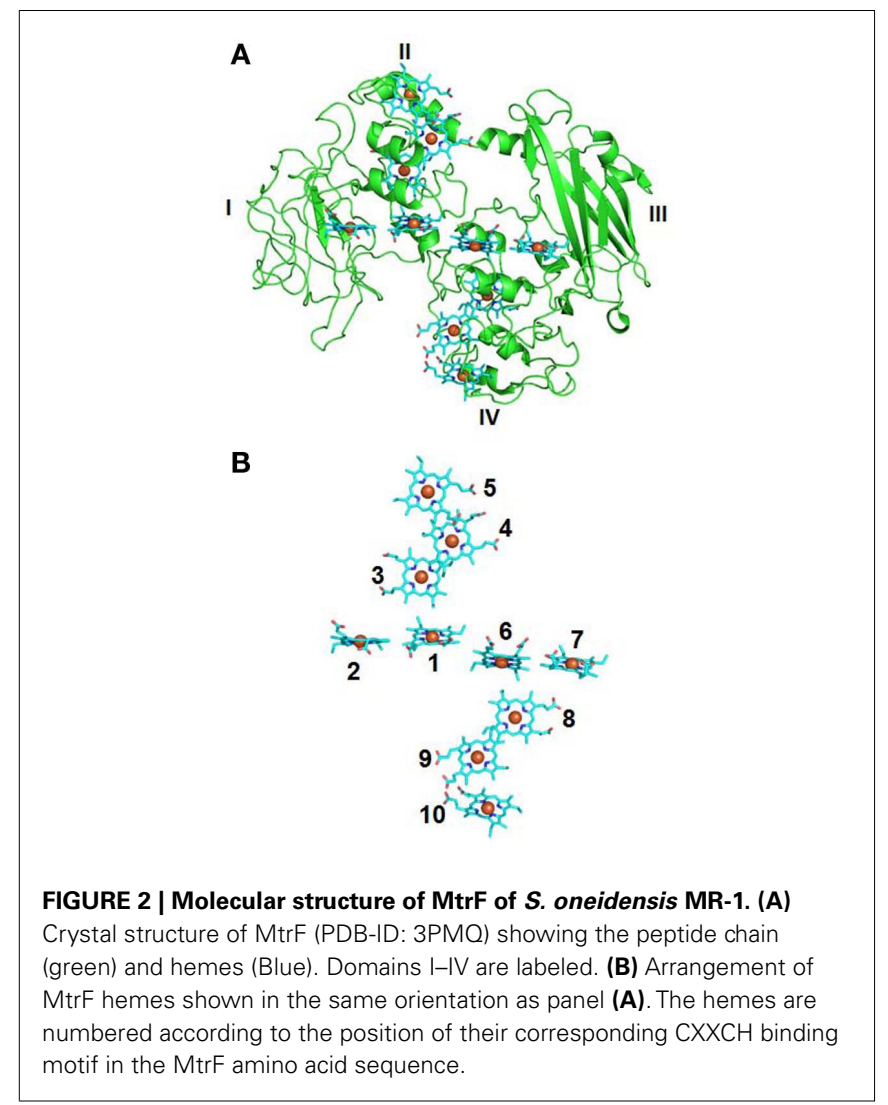

directly to the oxides via the solvent-exposed heme 5. Domain I and III are thought to be involved in binding and reduction of flavins and soluble metals such as chelated $\mathrm{Fe}(\mathrm{III})$, while domain IV is predicted to physically interact with the MtrDE (MtrAB homologs) complex and exchange electrons with MtrD via heme 10 (Clarke et al., 2011). It should be noted that the functional roles of domain II and IV of MtrF are interchangeable and that the overall shape of MtrF is very similar to that of OmcA (Johs et al., 2010; Clarke et al., 2011); the latter suggests that MtrF and OmcA may fold similarly. Like MtrC and OmcA, MtrF also reduces $\mathrm{Fe}$ (III) oxides and flavins (Coursolle and Gralnick, 2010; Clarke et al., 2011). Thus, the structural characteristics of MtrF support the notion that bacterial surface-localized $c$-Cyts MtrC, MtrF, and OmcA transfer electrons directly to the surface of Fe(III) oxides via their solvent-exposed hemes, such as heme 5 or 10 of MtrF. They also support the notion that, in order to enhance their reaction rates, these $c$-Cyts also use flavins secreted by S. oneidensis MR-1 cells as diffusible co-factors (i.e., shuttles) for reduction of $\mathrm{Fe}$ (III) oxides. Because of the direct binding of the $c$-Cyts to the Fe(III) oxides, the distance that flavins diffuse between the putative flavinreducing sites in the $c$-Cyts and the surface of $\mathrm{Fe}$ (III) oxide can be very short [ $\sim 20 \AA$ between MtrF and Fe(III) oxide], which makes the shuttle-mediated electron transfer efficient. Given that they physically interact with each other in vivo, MtrC and OmcA may exchange electrons through diffusible flavins. MtrC, MtrF, and OmcA also reduce soluble Fe(III) complexed with different ligands (Shi et al., 2006; Borloo et al., 2007; Wang et al., 2008; Ross et al., 2009; Bucking et al., 2010; Coursolle and Gralnick, 2010; Clarke 
et al., 2011). Reduction of chelated Fe(III) by MtrC, MtrF, and OmcA, in principle, also occurs via their solvent-exposed hemes as well as the hemes adjacent to the flavin-binding domains (i.e., hemes 2 and 7 of MtrF).

Despite the detailed structural and electrochemical spectroscopic information becoming available for outer-membrane $c$ Cyts, the electron transfer step from hemes to shuttle molecules, such as flavins, or directly to terminal electron acceptors, such as $\mathrm{Fe}(\mathrm{III})$ oxide itself, remains difficult to isolate. Although solvent exposure of hemes is suggestive of a possible role as an interfacial electron transfer mediator (i.e., input or output redox site), many conditions must be met at the molecular scale for this process to be usefully efficient to the organism. Indeed, solvent exposure to an aqueous environment often intrinsically reduces heme electron transfer efficiency compared to that fully embedded within the protein; a higher reorganization energy and thus higher activation energy is associated with repolarizing a high dielectric medium, such as water, to move an electron from water-exposed donor heme to a water-solvated acceptor species (Marcus and Sutin, 1985). Exclusion of water between $c$-Cyts and an Fe(III) oxide surface is demonstrated with computational molecular simulation to be necessary to reduce both the reorganization energy and the interfacial electron transfer distance between heme groups of STC and $\mathrm{Fe}$ (III) sites in the oxide surface (Kerisit et al., 2007). It shows that STC docks with a solvent-exposed heme in direct contact to a hematite (001) surface in $89 \%$ of the approach simulations, but the frequency of specific heme contact does not correlate with solvent exposure but rather the formation of covalent bonds to the surface via heme proprionate groups. Furthermore, it is shown that heme-surface encounter orientations involving the porphyrin plane at $\sim 90^{\circ}$ with respect to the surface plane, along with heme Fe to surface Fe distances of 9-10 $\AA$, enable interfacial electron transfer rates consistent with overall macroscopic rates measured by protein film voltammetry.

In addition to bacterial cell surfaces, MtrC and OmcA are found to be associated with extracellular polymeric substances (EPS) where they are directly associated with hematite as well as $\mathrm{U}(\mathrm{IV}) \mathrm{O}_{2}$ and $\mathrm{Fe}(\mathrm{II})$-containing secondary mineral phases presumably because these are the sites for reducing U(VI) and ferrihydrite, respectively (Marshall et al., 2006; Lower et al., 2009; Reardon et al., 2010). Likewise, MtrC and OmcA are released to the growth medium and are also involved in the formation of chromium $[\mathrm{Cr}(\mathrm{III})]$ precipitates that are found in the extracellular matrix following reduction of $\mathrm{Cr}(\mathrm{VI})$ by S. oneidensis MR-1 (Shi et al., 2008; Belchik et al., 2011). Global proteomic and Western blot analyses show that the homologs of MtrC and OmcA are the key components of the bound and loosely associated EPS isolated from the biofilm of the metal-reducing bacterium Shewanella sp HRCR-1 (Cao et al., 2011b). Interestingly, while an MtrB homolog was present in the isolated EPS, no MtrA homolog was detected (Cao et al., 2011b). MtrC and OmcA homologs in these isolated EPS are also implicated in $\mathrm{U}(\mathrm{VI})$ reduction (Cao et al., 2011a). These results suggest that after they are released from the bacterial cell surface, MtrB, MtrC, and OmcA may not be in association with MtrA. Although their roles in Fe(III) oxide reduction and their relationship with Shewanella nanowires and the outer-membrane vesicles are currently uncharacterized, it is proposed that EPS-associated MtrC, OmcA, and probably MtrB may be part of non-local electron transfer strategy used by S. oneidensis MR-1 for reduction of the $\mathrm{Fe}$ (III) oxide minerals distant from the bacterial cell surface (Rosso et al., 2003; Gorby et al., 2008; Bose et al., 2009; Lower et al., 2009).

\section{CONCLUDING REMARKS}

Recent in vivo and especially in vitro characterizations of Mtr and related proteins of $S$. oneidensis MR-1 have significantly advanced our understanding of the molecular mechanisms by which bacteria reduce $\mathrm{Fe}(\mathrm{III})$ oxides. These proteins, most of which are $c$-Cyts with multiple hemes, are strategically positioned along the width of the bacterial envelope. Through protein-protein interactions, they form a pathway for electron conductance across entire bacterial cell envelope to the surface of $\mathrm{Fe}$ (III) oxides. The electron conductance is mediated mainly by the heme groups of the $c$-Cyts. The quinol in the inner-membrane is believed to be oxidized by the heme 1 of CymA. Released electrons most likely

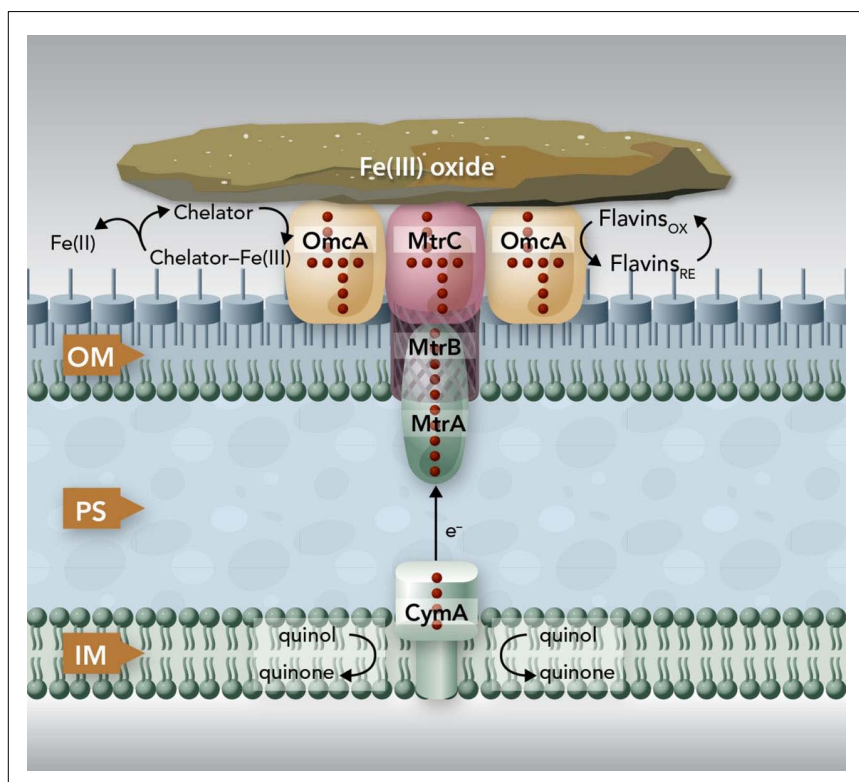

FIGURE 3 |The proposed Mtr extracellular electron transfer pathway of S. oneidensis MR-1. The protein components identified to date for the Mtr pathway include CymA, MtrA, MtrB, MtrC, and OmcA. CymA is a tetraheme $c$-Cyt that belongs to the $\mathrm{NapC} / \mathrm{NrfH}$ family of quinol dehydrogenases. Through its $\mathrm{N}$-terminal region, CymA is anchored in the inner-membrane (IM) where it oxidizes quinol in the IM and transfers the released electrons to MtrA in the outer-membrane (OM) either directly or indirectly via other periplasmic proteins. MtrA is a decaheme $c$-Cyt that is thought to be embedded in MtrB, a trans OM, and porin-like protein. Together, MtrAB facilitate the electron transfer across the $\mathrm{OM}$ to the $\mathrm{MtrC}$ and $\mathrm{OmcA}$ on the bacterial surface. Both MtrC and OmcA are the OM decaheme $c$-Cyts that are translocated across the $\mathrm{OM}$ by the bacterial type II secretion system. $\mathrm{MtrC}$ and OmcA are the terminal reductases that bind the surface of $\mathrm{Fe}$ (III) oxides and transfer electrons directly to the oxides via their

solvent-exposed hemes. To increase their reaction rates, MtrC and OmcA use flavins secreted by the $S$. oneidensis MR-1 cells as diffusible co-factors or shuttles for Fe(III) oxide reductions. MtrC and OmcA can also serve as the terminal reductases for the Fe(III) solubilized from the Fe(III) oxides by the Fe(III)-complexing ligands secreted from the S. oneidensis MR-1 cells. The sizes of the components depicted are not drawn to the scale. 
move along the heme groups of CymA. Through the heme 4, CymA transfers the electrons to MtrA either directly or indirectly via other periplasmic proteins. Inserted into the trans outermembrane porin formed by MtrB, MtrA transfers electron across the outer-membrane to MtrC and OmcA on the bacterial surface. MtrC and OmcA bind the surface of Fe(III) oxides and transfer electrons directly to $\mathrm{Fe}$ (III) via their solvent-exposed hemes. Through direct binding and reduction, MtrC and OmcA also use flavins as diffusible shuttles for Fe(III) oxide reduction. Because of their extracellular location, broad redox potentials, and ability to reduce $\mathrm{Fe}$ (III) complexed with different ligands in vitro, MtrC and OmcA can also reduce complexed forms of $\mathrm{Fe}(\mathrm{III})$ in vivo (Figure 3).

Despite the advances in understanding the molecular mechanisms of Fe(III) oxide reduction by S. oneidensis MR-1, key knowledge gaps still remain regarding the critical steps of the Mtr electron transfer pathway. First, it is still unclear which heme groups of the outer-membrane $c$-Cyts are directly involved in reduction of $\mathrm{Fe}$ (III) oxides and flavins. The molecular structure of MtrF predicts that heme 5 and 10 are highly solvent-exposed and thus candidates for interfacial electron transfer from MtrF to $\mathrm{Fe}$ (III) oxides, while hemes 2 and 7 are likely involved in flavin reduction. These predictions can be readily tested using site-directed mutagenesis. How the identified heme groups of MtrF interacts with and mediates the interfacial electron transfer to $\mathrm{Fe}$ (III) oxides and how MtrF binds and reduces flavins also need to be investigated, preferably using an integrated experiment and molecular modeling approach. Second, how MtrABC interact with each other to facilitate electrons transfer across the bacterial outer-membrane has yet to be determined. Structural determination of the MtrABC complex by X-ray crystallography could provide key insights of

\section{REFERENCES}

Belchik, S. M., Kennedy, D. W., Dohnalkova, A. C., Wang, Y., Sevinc, P. C., Wu, H., Lin, Y., Lu, H. P., Fredrickson, J. K., and Shi, L. (2011). Extracellular reduction of hexavalant chromium by cytochromes MtrC and OmcA of Shewanella oneidensis MR1. Appl. Environ. Microbiol. 77, 4035-4041.

Beliaev, A. S., and Saffarini, D. A. (1998). Shewanella putrefaciens $m$ trB encodes an outer membrane protein required for $\mathrm{Fe}(\mathrm{III})$ and $\mathrm{Mn}(\mathrm{IV})$ reduction. J. Bacteriol. 180, 6292-6297.

Beliaev, A. S., Saffarini, D. A., McLaughlin, J. L., and Hunnicutt, D. (2001). MtrC, an outer membrane decahaem c cytochrome required for metal reduction in Shewanella putrefaciens MR-1. Mol. Microbiol. 39, 722-730.

Bodemer, G. J., Antholine, W. A., Basova, L. V., Saffarini, D., and Pacheco, A. A. (2010). The effect of detergents and lipids on the properties of

the electron conductance mechanism through the bacterial outermembrane. Given that MtrABC is a trans outer-membrane protein complex, determination of its molecular structure will be challenging. Third, how electrons are transferred from CymA to MtrA remains unclear. Identification of this electron transfer mechanism will help determine how electrons are delivered across the bacterial periplasm. Another major knowledge gap is that the molecular details regarding how CymA interacts with and oxidizes the quinol in the inner-membrane are currently unclear. Determination of CymA structure will enable insights into how it binds and oxidizes quinol at the molecular-level. Finally, what are the functional roles of the MtrC and OmcA associated with EPS? Their relationship to bacterial outer-membrane vesicles and conductive nanowire also needs to be thoroughly characterized. Characterization of their roles will help understand the non-local electron transfer mechanisms by which $S$. oneidensis MR-1 cells reduce the $\mathrm{Fe}$ (III) oxide minerals distant from the cell surface. Although these key knowledge gaps persist, Mtr pathway of S. oneidensis MR-1 is the best characterized microbial pathway used for extracellular electron transfer. Characterization of the Mtr pathway has enabled unprecedented molecular-level understanding of microbial reduction of $\mathrm{Fe}$ (III) oxides.

\section{ACKNOWLEDGMENTS}

The authors would like to thank the U.S. Department of Energy (DOE) Office of Biological and Environmental Science's Subsurface Biogeochemical Research Program (SBR) for its support under the Pacific Northwest National Laboratory SBR Scientific Focus Area. The Pacific Northwest National Laboratory is operated for DOE by Battelle Memorial Institute under Contract DE-AC05-76RLO1830.

and metal oxide reduction by Shewanella oneidensis MR-1 wild type and mutants. Appl. Environ. Microbiol. 73, 7003-7012.

Bucking, C., Popp, F., Kerzenmacher, S., and Gescher, J. (2010). Involvement and specificity of Shewanella oneidensis outer membrane cytochromes in the reduction of soluble and solid-phase terminal electron acceptors. FEMS Microbiol. Lett. 306, 144-151.

Cao, B., Ahmed, B., Kennedy, D. W., Wang, Z., Shi, L., Marshall, M. J., Fredrickson, J. K., Isern, N. G., Majors, P. D., and Beyenal, H. (2011a). Contribution of extracellular polymeric substances from Shewanella sp. HRCR-1 biofilms to U(VI) immobilization. Environ. Sci. Technol. 45, 5483-5490.

Cao, B., Shi, L., Brown, R. N., Xiong, Y., Fredrickson, J. K., Romine, M. F., Marshall, M. J., Lipton, M. S., and Beyenal, H. (2011b). Extracellular polymeric substances from Shewanella sp. HRCR-1 biofilms: characterization by infrared spectroscopy and proteomics Environ. Microbiol. 13, 1018-1031.

Clarke, T. A., Cole, J. A., Richardson, D. J., and Hemmings, A. M. (2007). The crystal structure of the pentahaem $c$-type cytochrome $\mathrm{NrfB}$ and characterization of its solution-state interaction with the pentahaem nitrite reductase NrfA. Biochem. J. 406, 19-30.

Clarke, T. A., Edwards, M. J., Gates, A. J., Hall, A., White, G. F., Bradley, J., Reardon, C. L., Shi, L., Beliaev, A. S., Marshall, M. J., Wang, Z., Watmough, N. J., Fredrickson, J. K., Zachara, J. M., Butt, J. N., and Richardson, D. J. (2011). Structure of a bacterial cell surface decaheme electron conduit. Proc. Natl. Acad. Sci. U.S.A. 108, 9384-9389.

Clarke, T. A., Holley, T., Hartshorne, R. S., Fredrickson, J. K., Zachara, J. M., Shi, L., and Richardson, D. J. (2008). The role of multihaem cytochromes in the respiration of nitrite in Escherichia coli and Fe(III) in Shewanella oneidensis. Biochem. Soc. Trans. 36, 1005-1010. 
Coursolle, D., Baron, D. B., Bond, D. R., and Gralnick, J. A. (2010). The Mtr respiratory pathway is essential for reducing flavins and electrodes in Shewanella oneidensis. J. Bacteriol. 192, 467-474.

Coursolle, D., and Gralnick, J. A. (2010). Modularity of the Mtr respiratory pathway of Shewanella oneidensis strain MR-1. Mol. Microbiol. 77, 995-1008.

DiChristina, T. J., Moore, C. M., and Haller, C. A. (2002). Dissimilatory $\mathrm{Fe}(\mathrm{III})$ and $\mathrm{Mn}(\mathrm{IV})$ reduction by Shewanella putrefaciens requires ferE, a homolog of the pulE ( $g s p E)$ type II protein secretion gene. J. Bacteriol. 184, 142-151.

Dohnalkova, A. C., Marshall, M. J., Arey, B. W., Williams, K. H., Buck, E. C., and Fredrickson, J. K. (2011). Imaging hydrated microbial extracellular polymers: comparative analysis by electron microscopy. Appl. Environ. Microbiol. 77, 1254-1262.

Donald, J. W., Hicks, M. G., Richardson, D. J., and Palmer, T. (2008). The $c$-type cytochrome OmcA localizes to the outer membrane upon heterologous expression in Escherichia coli. J. Bacteriol. 190, 5127-5131.

Eggleston, C. M., Vörös, J., Shi, L., Lower, B. H., Droubay, T. C., and Colberg, P. J. S. (2008). Binding and direct electrochemistry of OmcA, an outer-membrane cytochrome from an iron reducing bacterium, with oxide electrode: a candidate biofuel system. Inorganica Chim. Acta 361, 769-777.

El-Naggar, M. Y., Gorby, Y. A., Xia, W., and Nealson, K. H. (2008). The molecular density of states in bacterial nanowires. Biophys. J. 95, L10-L12.

El-Naggar, M. Y., Wanger, G., Leung, K. M., Yuzvinsky, T. D., Southam, G., Yang, J., Lau, W. M., Nealson, K. H., and Gorby, Y. A. (2010). Electrical transport along bacterial nanowires from Shewanella oneidensis MR-1. Proc. Natl. Acad. Sci. U.S.A. 107, 18127-18131.

Field, S. J., Dobbin, P. S., Cheesman, M. R., Watmough, N. J., Thomson, A. J., and Richardson, D. J. (2000). Purification and magnetooptical spectroscopic characterization of cytoplasmic membrane and outer membrane multiheme $c$ type cytochromes from Shewanella frigidimarina NCIMB400. J. Biol. Chem. 275, 8515-8522.

Firer-Sherwood, M., Pulcu, G. S., and Elliott, S. J. (2008).
Electrochemical interrogations of the Mtr cytochromes from Shewanella: opening a potential window. J. Biol. Inorg. Chem. 13, 849-854.

Firer-Sherwood, M. A., Ando, N., Drennan, C. L., and Elliott, S. J. (2011a). Solution-based structural analysis of the decaheme cytochrome, MtrA, by small angle $\mathrm{X}$-ray scattering and analytical ultracentrifugation. J. Phys. Chem. B 115, 11208-11214.

Firer-Sherwood, M. A., Bewley, K. D., Mock, J. Y., and Elliott, S. J. (2011b). Tools for resolving complexity in the electron transfer networks of multiheme cytochromes c. Metallomics 3, 344-348.

Fredrickson, J. K., Romine, M. F., Beliaev, A. S., Auchtung, J. M., Driscoll, M. E., Gardner, T. S., Nealson, K. H., Osterman, A. L., Pinchuk, G., Reed, J. L., Rodionov, D. A., Rodrigues, J. L., Saffarini, D. A., Serres, M. H., Spormann, A. M., Zhulin, I. B., and Tiedje, J. M. (2008). Towards environmental systems biology of Shewanella. Nat. Rev. Microbiol. 6, 592-603.

Fredrickson, J. K., and Zachara, J. M. (2008). Electron transfer at the microbe-mineral interface: a grand challenge in biogeochemistry. Geobiology 6, 245-243.

Gorby, Y., McLean, J., Korenevsky, A., Rosso, K., El-Naggar, M. Y., and Beveridge, T. J. (2008). Redoxreactive membrane vesicles produced by Shewanella. Geobiology 6, 232-241.

Gorby, Y. A., Yanina, S., McLean, J. S., Rosso, K. M., Moyles, D., Dohnalkova, A., Beveridge, T. J., Chang, I. S., Kim, B. H., Kim, K. S., Culley, D. E., Reed, S. B., Romine, M. F., Saffarini, D. A., Hill, E. A., Shi, L., Elias, D. A., Kennedy, D. W., Pinchuk, G., Watanabe, K., Ishii, S., Logan, B., Nealson, K. H., and Fredrickson, J. K. (2006). Electrically conductive bacterial nanowires produced by Shewanella oneidensis strain MR-1 and other microorganisms. Proc. Natl. Acad. Sci. U.S.A. 103, 11358-11363.

Gralnick, J. A., Vali, H., Lies, D. P., and Newman, D. K. (2006). Extracellular respiration of dimethyl sulfoxide by Shewanella oneidensis strain MR1. Proc. Natl. Acad. Sci. U.S.A. 103, 4669-4674.

Hartshorne, R. S., Jepson, B. N., Clarke, T. A., Field, S. J., Fredrickson, J., Zachara, J., Shi, L., Butt, J. N., and Richardson, D. J. (2007). Characterization of Shewanella oneidensis MtrC: a cell-surface decaheme cytochrome involved in respiratory electron transport to extracellular electron acceptors. J. Biol. Inorg. Chem. 12, 1083-1094.

Hartshorne, R. S., Reardon, C. L., Ross, D., Nuester, J., Clarke, T. A., Gates, A. J., Mills, P. C., Fredrickson, J. K., Zachara, J. M., Shi, L., Beliaev, A. S., Marshall, M. J., Tien, M., Brantley, S., Butt, J. N., and Richardson, D. J. (2009). Characterization of an electron conduit between bacteria and the extracellular environment. Proc. Natl. Acad. Sci. U.S.A. 106 22169-22174.

Hau, H. H., and Gralnick, J. A. (2007). Ecology and biotechnology of the genus Shewanella. Annu. Rev. Microbiol. 61, 237-258.

Jensen, H. M., Albers, A. E., Malley, K. R., Londer, Y. Y., Cohen, B. E., Helms, B. A., Weigele, P., Groves, J. T., and Ajo-Franklin, C. M. (2010). Engineering of a synthetic electron conduit in living cells. Proc. Natl. Acad. Sci. U.S.A. 107, 19213-19218.

Jiao, Y., and Newman, D. K. (2007). The pio operon is essential for phototrophic $\mathrm{Fe}(\mathrm{II})$ oxidation in Rhodopseudomonas palustris TIE-1. J. Bacteriol. 189, 1765-1773.

Johs, A., Shi, L., Droubay, T., Ankner, J. F., and Liang, L. (2010). Characterization of the decaheme $c$ type cytochrome OmcA in solution and on hematite surfaces by small angle $x$-ray scattering and neutron reflectometry. Biophys. J. 98, 3035-3043.

Jones, M. E., Fennessey, C. M., DiChristina, T. J., and Taillefert, M. (2010). Shewanella oneidensis MR-1 mutants selected for their inability to produce soluble organic$\mathrm{Fe}(\mathrm{III})$ complexes are unable to respire $\mathrm{Fe}(\mathrm{III})$ as anaerobic electron acceptor. Environ. Microbiol. 12, 938-950.

Kerisit, S. N., Rosso, K. M., Dupuis, M., and Valiev, M. (2007). Molecular computational investigation of electron transfer kinetics across cytochrome-iron oxide interfaces. J. Phys. Chem. C 111, 11363-11375.

Lies, D. P., Hernandez, M. E., Kappler, A., Mielke, R. E., Gralnick, J. A., and Newman, D. K. (2005). Shewanella oneidensis MR-1 uses overlapping pathways for iron reduction at a distance and by direct contact under conditions relevant for biofilms. Appl. Environ. Microbiol. 71, 4414-4426.

Lower, B. H., Lins, R. D., Oestreicher, Z., Straatsma, T. P., Hochella, M. F. Jr., Shi, L., and Lower, S.
K. (2008). In vitro evolution of a peptide with a hematite binding motif that may constitute a natural metal-oxide binding archetype. Environ. Sci. Technol. 42, 3821-3827.

Lower, B. H., Shi, L., Yongsunthon, R., Droubay, T. C., McCready, D. E., and Lower, S. K. (2007). Specific bonds between an iron oxide surface and outer membrane cytochromes MtrC and OmcA from Shewanella oneidensis MR-1. J. Bacteriol. 189, 4944-4952.

Lower, B. H., Yongsunthon, R., Shi, L., Wildling, L., Gruber, H. J., Wigginton, N. S., Reardon, C. L., Pinchuk, G. E., Droubay, T. C., Boily, J. F., and Lower, S. K. (2009). Antibody recognition force microscopy shows that outer membrane cytochromes OmcA and MtrC are expressed on the exterior surface of Shewanella oneidensis MR1. Appl. Environ. Microbiol. 75, 2931-2935.

Lower, S. K., Hochella, M. F. Jr., and Beveridge, T. J. (2001). Bacterial recognition of mineral surfaces: nanoscale interactions between She wanella and alpha-FeOOH. Science 292, 1360-1363.

Marcus, R. A., and Sutin, N. (1985). Electron transfers in chemistry and biology. Biochim. Biophys. Acta 811, 265-322.

Marshall, M. J., Beliaev, A. S., Dohnalkova, A. C., Kennedy, D. W., Shi, L., Wang, Z., Boyanov, M. I., Lai, B., Kemner, K. M. McLean, J. S., Reed, S. B., Culley, D. E., Bailey, V. L., Simonson, C. J., Saffarini, D. A., Romine, M. F., Zachara, J. M., and Fredrickson, J. K. (2006). c-Type cytochromedependent formation of U(IV) nanoparticles by Shewanella oneidensis. PLoS Biol. 4, e268. doi: 10.1371/journal.pbio.0040268

Marshall, M. J., Plymale, A. E., Kennedy, D. W., Shi, L., Wang, Z., Reed, S. B., Dohnalkova, A. C., Simonson, C. J., Liu, C., Saffarini, D. A., Romine, M. F., Zachara, J. M., Beliaev, A S., and Fredrickson, J. K. (2008) Hydrogenase- and outer membrane $c$-type cytochrome-facilitated reduction of technetium(VII) by Shewanella oneidensis MR1. Environ. Microbiol. 10, 125-136.

Marsili, E., Baron, D. B., Shikhare, I. D., Coursolle, D., Gralnick, J. A., and Bond, D. R. (2008). Shewanella secretes flavins that mediate extracellular electron transfer. Proc. Natl. Acad. Sci. U.S.A. 105, 3968-3973. 
Matias, V. R., Al-Amoudi, A., Dubochet, J., and Beveridge, T. J. (2003). Cryotransmission electron microscopy of frozen-hydrated sections of Escherichia coli and Pseudomonas aeruginosa. J. Bacteriol. 185, 6112-6118.

Meitl, L. A., Eggleston, C. M., Colberg, P. J. S., Khare, N., Reardon, C. L., and Shi, L. (2009). Electrochemical interaction of Shewanella oneidensis MR-1 and its outer membrane cytochromes OmcA and MtrC with hematite electrodes. Geochim. Cosmochim. Acta 2009, 5292-5307.

Murphy, J. N., and Saltikov, C. W. (2007). The cymA gene, encoding a tetraheme $c$-type cytochrome, is required for arsenate respiration in Shewanella species. J. Bacteriol. 189, 2283-2290.

Myers, C. R., and Myers, J. M. (1997a). Cloning and sequence of cymA, a gene encoding a tetraheme cytochrome $c$ required for reduction of iron(III), fumarate, and nitrate by Shewanella putrefaciens MR-1. J. Bacteriol. 179, 1143-1152.

Myers, C. R., and Myers, J. M. (1997b). Outer membrane cytochromes of Shewanella putrefaciens MR-1: spectral analysis, and purification of the $83-\mathrm{kDa} c$-type cytochrome. Biochim. Biophys. Acta 1326, 307-318.

Myers, C. R., and Myers, J. M. (2002). MtrB is required for proper incorporation of the cytochromes OmcA and $\mathrm{OmcB}$ into the outer membrane of Shewanella putrefaciens MR-1. Appl. Environ. Microbiol. 68, 5585-5594.

Myers, C. R., and Myers, J. M. (2003). Cell surface exposure of the outer membrane cytochromes of Shewanella oneidensis MR-1. Lett. Appl. Microbiol. 37, 254-258.

Myers, C. R., and Nealson, K. H. (1990). Respiration-linked proton translocation coupled to anaerobic reduction of manganese(IV) and iron(III) in Shewanella putrefaciens MR-1. J. Bacteriol. 172, 6232-6238.

Nealson, K. H., and Scott, J. (eds). (2003). Ecophysiology of the genus Shewanella. The Prokaryotes: An Evolving Electronic Resource for the Microbial Community. New York, NY: Springer, LLC.

Pitts, K. E., Dobbin, P. S., ReyesRamirez, F., Thomson, A. J., Richardson, D. J., and Seward, H. E. (2003). Characterization of the Shewanella oneidensis MR-1 decaheme cytochrome MtrA: expression in Escherichia coli confers the ability to reduce soluble $\mathrm{Fe}(\mathrm{III})$ chelates. J. Biol. Chem. 278, 27758-27765.

Reardon, C. L., Dohnalkova, A. C., Nachimuthu, P., Kennedy, D. W., Saffarini, D. A., Arey, B. W., Shi, L., Wang, Z., Moore, D., McLean, J. S., Moyles, D., Marshall, M. J., Zachara, J. M., Fredrickson, J. K., and Beliaev, A. S. (2010). Role of outer-membrane cytochromes $\mathrm{MtrC}$ and OmcA in the biomineralization of ferrihydrite by Shewanella oneidensis MR-1. Geobiology 8, 56-68.

Richardson, D. J. (2000). Bacterial respiration: a flexible process for a changing environment. Microbiology 146(Pt 3), 551-571.

Rodrigues, M. L., Oliveira, T. F., Pereira, I. A., and Archer, M. (2006). $\mathrm{X}$-ray structure of the membranebound cytochrome c quinol dehydrogenase $\mathrm{NrfH}$ reveals novel haem coordination. EMBO J. 25, 5951-5960.

Rodrigues, M. L., Scott, K. A., Sansom, M. S., Pereira, I. A., and Archer, M. (2008). Quinol oxidation by $c$-type cytochromes: structural characterization of the menaquinol binding site of NrfHA. J. Mol. Biol. 381, 341-350.

Ross, D. E., Brantley, S. L., and Tien, M. (2009). Kinetic characterization of OmcA and MtrC, terminal reductases involved in respiratory electron transfer for dissimilatory iron reduction in Shewanella oneidensis MR-1. Appl. Environ. Microbiol. 75, 5218-5226.

Ross, D. E., Flynn, J. M., Baron, D. B., Gralnick, J. A., and Bond, D. R. (2011). Towards electrosynthesis in Shewanella: energetics of reversing the $m t r$ pathway for reductive metabolism. PLoS ONE 6, el6649. doi:10.1371/journal.pone.0016649

Ross, D. E., Ruebush, S. S., Brantley, S. L., Hartshorne, R. S., Clarke, T. A., Richardson, D. J., and Tien, M. (2007). Characterization of proteinprotein interactions involved in iron reduction by Shewanella oneidensis MR-1. Appl. Environ. Microbiol. 73, 5797-5808.

Rosso, K. M., Smith, D. M. A., Wang, Z., Ainsworth, C. C., and Fredrickson, J. K. (2004). Self-exchange electron transfer kinetics and reduction potentials for anthraquinone disulfonate. J. Phys. Chem. A 108, 3292-3303.

Rosso, K. M., Zachara, J. M., Fredrickson, J. K., Gorby, Y. A., and Smith, S. C. (2003). Nonlocal bacterial electron transfer to hematite surface. Geochim. Cosmochim. Acta 67, 1081-1087.
Schuetz, B., Schicklberger, M., Kuermann, J., Spormann, A. M., and Gescher, J. (2009). Periplasmic electron transfer via the $c$-type cytochromes MtrA and FccA of Shewanella oneidensis MR-1. Appl. Environ. Microbiol. 75, 7789-7796.

Schwalb, C., Chapman, S. K., and Reid, G. A. (2003). The tetraheme cytochrome CymA is required for anaerobic respiration with dimethyl sulfoxide and nitrite in Shewanella oneidensis. Biochemistry 42, 9491-9497.

Shi, L., Belchik, S. M., Wang, Z., Kennedy, D. W., Dohnalkova, A. C., Marshall, M. J., Zachara, J. M., and Fredrickson, J. K. (2011). Identification and characterization of UndAHRCR-6, an outer membrane endecaheme $c$-type cytochrome of Shewanella sp. strain HRCR-6. Appl. Environ. Microbiol. 77, 5521-5523.

Shi, L., Chen, B., Wang, Z., Elias, D. A., Mayer, M. U., Gorby, Y. A., Ni, S., Lower, B. H., Kennedy, D. W. Wunschel, D. S., Mottaz, H. M., Marshall, M. J., Hill, E. A., Beliaev, A. S., Zachara, J. M., Fredrickson, J. K., and Squier, T. C. (2006). Isolation of a high-affinity functional protein complex between OmcA and MtrC: two outer membrane decaheme $c$-type cytochromes of Shewanella oneidensis MR-1. J. Bacteriol. 188, 4705-4714.

Shi, L., Deng, S., Marshall, M. J., Wang, Z., Kennedy, D. W., Dohnalkova, A. C., Mottaz, H. M., Hill, E. A., Gorby, Y. A., Beliaev, A. S., Richardson, D. J. Zachara, J. M., and Fredrickson, J. K. (2008). Direct involvement of type II secretion system in extracellular translocation of Shewanella oneidensis outer membrane cytochromes MtrC and OmcA. J. Bacteriol. 190, 5512-5516.

Shi, L., Lin, J. T., Markillie, L. M., Squier, T. C., and Hooker, B. S. (2005). Overexpression of multi-heme Ctype cytochromes. Biotechniques 38, 297-299.

Shi, L., Richardson, D. J., Wang, Z., Kerisit, S. N., Rosso, K. M., Zachara, J. M., and Fredrickson, J. K. (2009). The roles of outer membrane cytochromes of Shewanella and Geobacter in extracellular electron transfer. Environ. Microbiol. Rep. 1, 220-227.

Shi, L., Squier, T. C., Zachara, J. M., and Fredrickson, J. K. (2007). Respiration of metal (hydr)oxides by Shewanella and Geobacter: a key role for multihaem $c$-type cytochromes. Mol. Microbiol. 65, 12-20.

Simon, J., and Kern, M. (2008). Quinone-reactive proteins devoid of haem $b$ form widespread membrane-bound electron transport modules in bacterial respiration. Biochem. Soc. Trans. 36 , 1011-1016.

Stack, A. G., Rosso, K. M., Smith, D. M. A., and Eggleston, C. M (2004). Reaction of hydroquinone with hematite II. Calculated electron transfer rates and comparison to the reductive dissolution rate. J. Colloid Interface Sci. 274, 442-450.

Tang, X., Yi, W., Munske, G. R., Adhikari, D. P., Zakharova, N. L., and Bruce, J. E. (2007). Profiling the membrane proteome of Shewanella oneidensis MR-1 with new affinity labeling probes. J. Proteome Res. 6, 724-734.

Thamdrup, B. (2000). Bacterial mangannese and iron reduction in aquatic sediments. Adv. Microb. Ecol. $16,41-84$.

von Canstein, H., Ogawa, J., Shimizu, S., and Lloyd, J. R. (2008). Secretion of flavins by Shewanella species and their role in extracellular electron transfer. Appl. Environ. Microbiol. 74, 615-623.

Wang, Z., Liu, C., Wang, X., Marshall, M. J., Zachara, J. M., Rosso, K. M., Dupuis, M., Fredrickson, J. K., Heald, S., and Shi, L. (2008). Kinetics of reduction of $\mathrm{Fe}$ (III) complexes by outer membrane cytochromes MtrC and OmcA of Shewanella oneidensis MR-1. Appl. Environ. Microbiol. 74, 6746-6755

Weber, K. A., Achenbach, L. A., and Coates, J. D. (2006). Microorganisms pumping iron: anaerobic microbial iron oxidation and reduction. Nat. Rev. Microbiol. 4, 752-764.

Wigginton, N. S., Rosso, K. M., and Hochella, M. F. (2007a). Mechanisms of electron transfer in two decaheme cytochromes from a metal-reducing bacterium. J. Phys. Chem. B 111, 12857-12864.

Wigginton, N. S., Rosso, K. M., Lower B. H., Shi, L., and Hochella, M. F. (2007b). Electron tunneling properties of outer-membrane decaheme cytochromes from Shewanella oneidensis. Geochim. Cosmochim. Acto 71, 543-555.

Xiong, Y., Shi, L., Chen, B., Mayer, M. U., Lower, B. H., Londer, Y. Bose, S., Hochella, M. F., Fredrickson, J. K., and Squier, T. C. (2006). High-affinity binding and direct electron transfer to solid metals by the Shewanella oneidensis MR-1 outer membrane $c$-type cytochrome OmcA. J. Am. Chem. Soc. 128, 13978-13979.

Zachara, J. M., Fredrickson, J. K., Li, S. M., Kennedy, D. W., Smith, S. C. and Gassman, P. L. (1998). Bacterial 
reduction of crystalline $\mathrm{Fe}^{3+}$ oxides in single phase suspensions and subsurface materials. Am. Mineral. 83, 1426-1443.

Zhang, H., Tang, X., Munske, G. R., Tolic, N., Anderson, G. A., and Bruce, J. E. (2009). Identification of protein-protein interactions and topologies in living cells with chemical cross-linking and mass spectrometry. Mol. Cell. Proteomic 8, 409-420.

Zhang, H., Tang, X., Munske, G. R., Zakharova, N., Yang, L., Zheng,
C., Wolff, M. A., Tolic, N., Anderson, G. A., Shi, L., Marshall, M. J., Fredrickson, J. K., and Bruce, J. E. (2008). In vivo identification of the outer membrane protein OmcA-MtrC interaction network in Shewanella oneidensis MR-1 cells using novel hydrophobic chemical cross-linkers. J. Proteome Res. 7, 1712-1720.

Conflict of Interest Statement: The authors declare that the research was conducted in the absence of any commercial or financial relationships that could be construed as a potential conflict of interest.

Received: 15 October 2011; accepted: 30 January 2012; published online: $15 \mathrm{Feb}$ ruary 2012.

Citation: Shi L, Rosso KM, Clarke TA, Richardson DJ, Zachara JM and Fredrickson JK (2012) Molecular underpinnings of $\mathrm{Fe}$ (III) oxide reduction by Shewanella oneidensis
MR-1. Front. Microbio. 3:50. doi: 10.3389/fmicb.2012.00050

This article was submitted to Frontiers in Microbiological Chemistry, a specialty of Frontiers in Microbiology.

Copyright (C) 2012 Shi, Rosso, Clarke, Richardson, Zachara and Fredrickson. This is an open-access article distributed under the terms of the Creative Commons Attribution Non Commercial License, which permits non-commercial use, distribution, and reproduction in other forums, provided the original authors and source are credited. 